\title{
A CERAMIC TOOL FOR THE GLASS-BLOWER
}

\begin{abstract}
Summary. The existence of a local glass workshop is known at Sagalassos through archaeological and chemical analysis. In test soundings in the monumental city, an enigmatic ceramic cane was found attached to a chunk of green glass. This remarkable object is thought to be a pontil rod, more specifically a mandril. This study illustrates the use of ceramic tools in the glass craft as a readily available and cheap solution to the technical problems a glass-worker encountered.
\end{abstract}

\section{INTRODUCTION}

Located in the south-western region of Turkey, Sagalassos is situated in the territory known in antiquity as Asia Minor, more specifically in the region of Pisidia. The city of Sagalassos stretches along an east-west orientated plateau, immediately below the steep limestone upper slopes of the Ağlasun Dağlari Mountains.

Using the Roman Via Sebaste that crossed the territory of Sagalassos, linking the territories of Conana and Comama, the city was able to develop its natural resources into a flourishing economy. The remains of a large potters' quarter and tons of locally produced Sagalassos Red Slip Ware (produced from Late Hellenistic times to the early seventh century AD) provide a good indication for this.

\section{THE CONTEXT}

In previous studies the existence of a local glass workshop was confirmed through chemical (Degryse et al. 2005; 2006) and archaeological (Lauwers et al. 2005; in press) analysis. Archaeological evidence did not include structures related to glass-working, but did include the waste products from glass-blowing. While studying the urban development of the city through test soundings during the 2004 campaign, a remarkable but enigmatic object was found. A sequence showing the succeeding stadia of street levels was displayed. The sounding revealing this sequence was made at the junction of a secondary street running east-west and an important north-south axis leading to the Neon Library and the Hellenistic fountain house. A trench $5 \mathrm{~m}$ by $5 \mathrm{~m}$ was opened along the eastern edge of the north-south street in order to establish the chronology and layout of the adjoining domestic buildings. Layer 6, representing the foundation trench of the original house wall, was especially instructive. This layer contained finds related to glass production, primarily chunks of raw glass. A chunk of green glass attached to a ceramic 

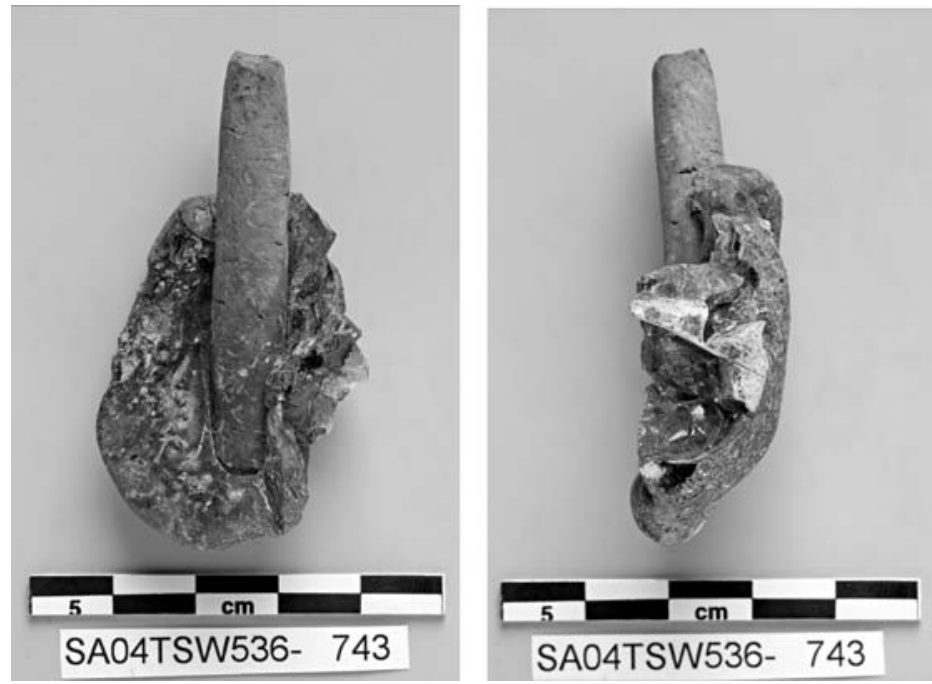

Figure 1

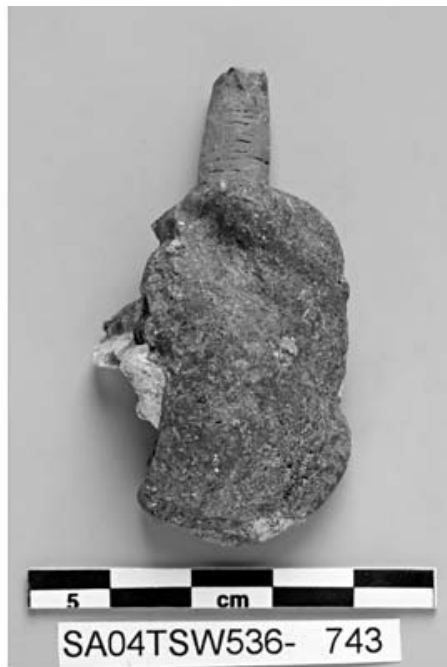

SA04TSW536- 743

Photograph of the ceramic cane with a glass chunk attached (photo: Bruno Vandermeulen).

stick was particularly striking (Fig. 1 and 2). Based on the chronology derived from Sagalassos Red Slip Ware, the ceramic content of the layer was exclusively dated to the Middle Imperial period, the second half of the third century AD. ${ }^{1}$ Although this assemblage represents a dump (identified by the large range in degree of fragmentation of artefacts and a very low average weight per rim sherd), given the quantity of the ceramic assemblage (1346 $\mathrm{g}$ or 112 rim fragments) and the overall chronological homogeneity of the pottery retrieved (with very few intrusive and residual fragments), we can say that the glass finds (none of which were diagnostic pieces) in this layer can also be attributed to this period.

\section{THE ANALYSIS}

The object concerned is a ceramic cane $5 \mathrm{~cm}$ long and with a width of $9 \mathrm{~mm}$. In section there is a dark grey core (7.5 YR N4/ in the Munsell system) in a brownish matrix (5YR 5/1) (Fig. 3). On the outside, where the stick was in direct contact with the glass mass, there is a greyish coloration $(2.5 \mathrm{Y} 8 / 2)$ with a dark grey lining $(2.5 \mathrm{Y} \mathrm{N} 4 /)$, while the remainder of the surface is brownish grey (5YR 5/1). Within this well-defined lighter area, there are several cracks, presumably due to shrinkage. The rest of the stick lacks such features. According to Frank Kentie, an experienced glass-blower affiliated with the University of Leuven, this phenomenon is due to the difference in the shrinkage rates of the glass and the clay. We successfully tested this hypothesis, and observed the replication of this phenomenon. After applying a cane to the hot mass, the clay cools much more rapidly than the glass and 'shrinks' away from the surrounding mass.

1 All ceramics were studied by J. Poblome, P. Bes (both I.C.R.A.T.E.S. project, Catholic University of Leuven), Yaprak Özkönü and Senem Özden (both students in archaeology at Istanbul University). 

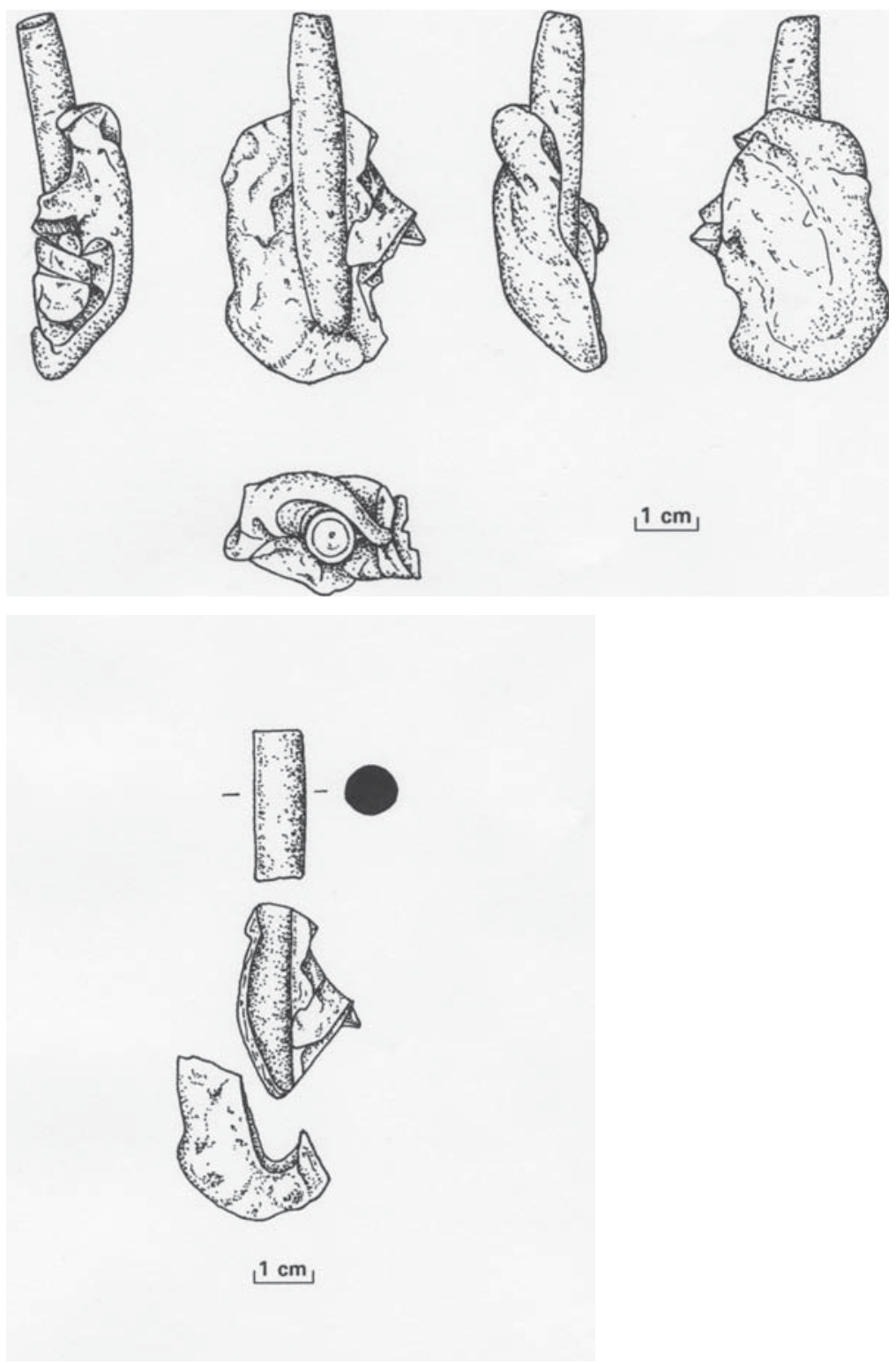

Figure 2

Drawing of the ceramic cane with a glass chunk attached (above) and detail of the glass and cane (below).

The ceramic pipe studied here has a major element chemistry identical to that of local Sagalassos Red Slip Ware (Table 1; compare to Poblome et al. 2002; Degryse et al. 2003) and is likely to have been made from the same lacustrine clay as the tableware. These clays were extracted approximately $7 \mathrm{~km}$ south of the site, in the Çanakli valley. The main clay minerals were chlorite and chlorite/smectite mixed with small amounts of illite and kaolin. Feldspars were 


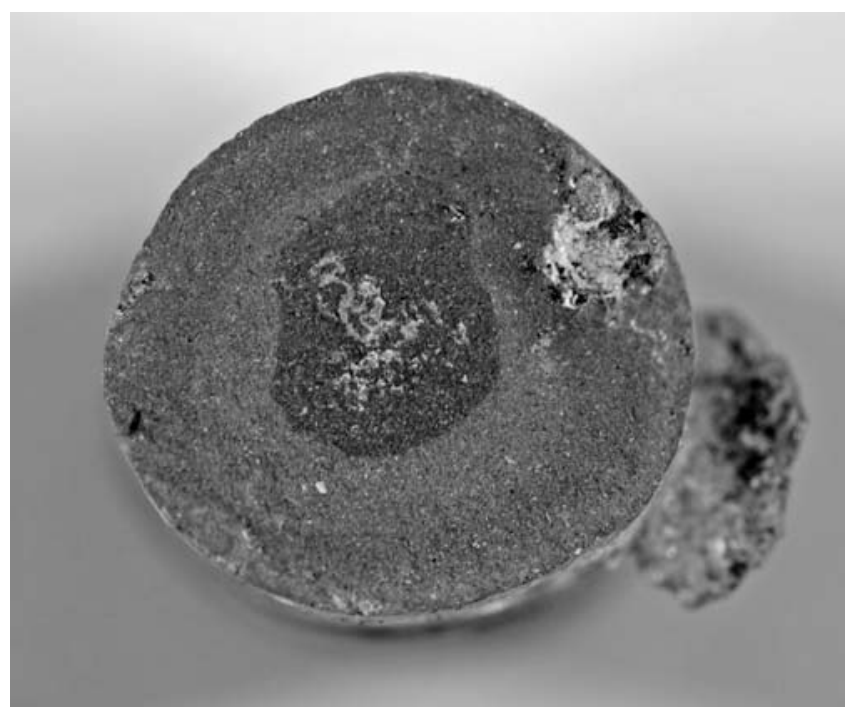

Figure 3

Section of the ceramic cane (photo: Veerle Lauwers).

TABLE 1

Major element chemical composition of the ceramic cane and the adhering glass

\begin{tabular}{llllllllllllll}
\hline Sample & $\mathrm{SiO}_{2}$ & $\mathrm{Al}_{2} \mathrm{O}_{3}$ & $\mathrm{Fe}_{2} \mathrm{O}_{3}$ & $\mathrm{MnO}$ & $\mathrm{MgO}$ & $\mathrm{CaO}$ & $\mathrm{Na}_{2} \mathrm{O}$ & $\mathrm{K}_{2} \mathrm{O}$ & $\mathrm{TiO}_{2}$ & $\mathrm{LOI}$ & $\mathrm{Total}$ & ${ }^{87} \mathrm{Sr} /{ }^{86} \mathrm{Sr}$ & $\mathrm{Sr}(\mathrm{ppm})$ \\
\hline Glass & 65.37 & 2.48 & 1.89 & 1.94 & 0.91 & 8.92 & 15.82 & 0.61 & 0.09 & 1.26 & 99.29 & 0.70872 & 634 \\
Ceramic pipe & 54.93 & 14.18 & 9.46 & 0.09 & 5.68 & 5.66 & 1.06 & 2.81 & 0.81 & 4.65 & 99.31 & no data & no data \\
\hline
\end{tabular}

LOI: loss on ignition

mainly plagioclase, with a lesser amount of K-feldspar, and there was a large quartz fraction (Degryse et al. 2003). The petrographical characteristics of the ceramic pipe are also very similar to those of Sagalassos Red Slip Ware, but are not identical (as the tableware was oxidized when fired, unlike the ceramic pipe discussed here). The overall structure is that of fine clay with very few mineral inclusions (some rounded quartz and pyroxene, $50 \mu \mathrm{m}$ in diameter). In some of the cracks and pores in the clay matrix, glass can be observed.

From the major element composition and the lead and strontium isotopic signature of the Early Byzantine pale blue vessel and chunk glass at Sagalassos, it was suggested that this type of local glass had at least two primary production locations, probably in the Levant (Degryse et al. 2005; 2006). Locally found Early Byzantine HIMT glass chunks corresponded in composition to the material studied by Freestone et al. (2005). These authors argue for an Egyptian origin for this HIMT glass. The Early Byzantine green vessel glass had a heterogeneous chemical composition, varying between the chemical compositions of on the one hand the local pale blue vessel and chunk glass and on the other the HIMT glass chunks, so that the Early Byzantine green glass was the outcome of recycling. $\mathrm{Pb}$ and $\mathrm{Sr}$ isotope mixing lines indicate that the green and HIMT vessel glass was locally recycled and that secondary production of these 


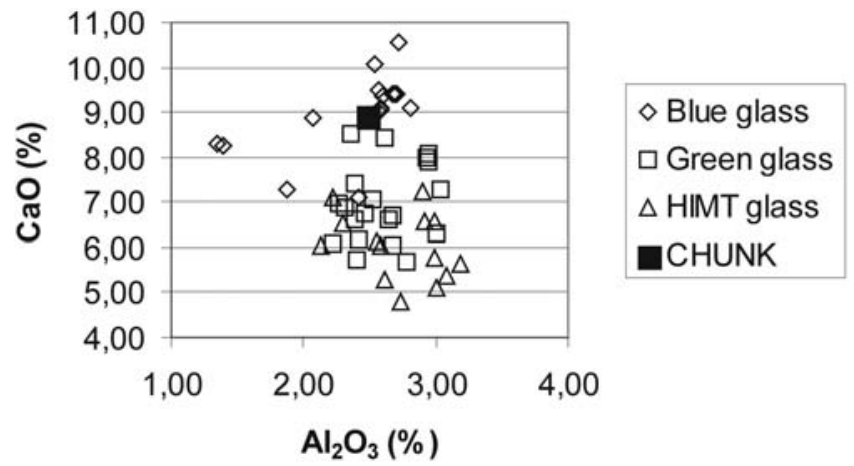

Figure 4

Major element chemical composition of the locally worked glass at Sagalassos.

types of glass occurred at Sagalassos. Remarkably the glass adhering to the ceramic cane corresponds in its major element chemical profile to the locally worked Early Byzantine bluegreen glass of Sagalassos (Table 1, Fig. 4). Together with the value of 0.7087 for the ${ }^{87} \mathrm{Sr} /{ }^{86} \mathrm{Sr}$ isotopic signature of the glass and its very high $\mathrm{Sr}$ content (634 ppm $\mathrm{Sr}$ for $8.92 \%$ of $\mathrm{CaO}$ ), this suggests a primary Levantine origin for this glass (compare to Wedepohl and Baumann 2000; Freestone et al. 2003; Henderson et al. 2005; Degryse et al. 2006).

\section{DISCUSSION}

Despite the data presented above, it is impossible to pinpoint the exact function of the artefact. So far, no equivalent artefacts have been found in the literature. The use of clay instruments or tools in the glass-blower's craft, however, was discussed by E.M. Stern as early as 1994 (Stern and Schliek-Nolte 1994, 81-6). In a series of articles and book chapters, she describes the hypothetical use of clay blowpipes by glass-workers in antiquity (Stern 1995, 39-42; 1999; 2001, 19; 2004; 2005). Through experiments carried out at the Toledo, Ohio Museum of Art, she demonstrated the possibility of blowing vessels from a heated chunk of glass with a ceramic pipe. Although glass-blowing with tubes made out of this lacustrine clay is possible, there are no indications that the Sagalassos cane is indeed the long-sought antique ceramic blowpipe.

Experiments undertaken at Leuven University and at the workshop of Danny Theys produced results comparable to those obtained by Stern. The tests done by Kentie initially demonstrated that it was possible to attach glass to the replica tube and blow vessels from it. Frank Kentie, however, is a lamp-worker, which means that he does not start from a liquid mass of glass in a crucible, heated in a kiln, but that he heats a pre-blown glass tube in a blowtorch until it becomes liquid. By working in this manner, one does not have to produce the high temperatures necessary in a traditional glass kiln. ${ }^{2}$ In contrast, Danny Theys, a traditional glass-blower from Leuven, made a futile attempt to pick up a gob of glass from the crucible in

2 Stern however doubts the spread of the lamp-working technique in antiquity, which proved to be more of a rarity (Stern and Schliek-Nolte 1994, 24). 
the kiln, owing to the short length of the replica blowpipe. When he picked up a gob of glass with the metal pontil and attached that to the ceramic tube, the paraison was already too stiff to be blown and needed to be reheated again. This was almost impossible, as the kiln was too hot to put one's arm in to heat the glass sufficiently. Taking all of this into account, if this was indeed a blowpipe, the only way to blow glass with it was by means of the so-called 'chunk gathering' method (Stern 1992; Stern and Schliek-Nolte 1994).

It seems more likely to be a pontil rod, ${ }^{3}$ and more specifically a mandril (according to Stern 2001, 20: 'a solid iron rod with a rounded or pointed tip, much lighter and smaller than a modern punty. Known primarily as a bead maker's tool, the ancient glassblower probably had several mandrils at hand to apply decorative threads, blobs, etc. Bent mandrils with a curved or hook-shaped tip were used to drag glass threads into loops, festoons, zigzags, etc.'). Frank Kentie describes the similar use of very small clay pontils embedded in a metal rod to stir a small quantity of precious paraison (glass melt) in the Philips factories in Eindhoven, The Netherlands, in the early Seventies. Further information on this could not, however, be found by the authors.

The closest parallel we found in the literature to the pieces of glass surrounding the cane is that described by Heidi Amrein $(2001,34)$ as 'les fragments portant une empreinte de tige'. These fragments bearing imprints of a cane have an irregular shape, but are rounded on the outside. The longitudinal imprint has a semi-circular section which is completely covered with a brownish or blackish metallic layer. These imprints are the negative traces of the use of a pontil on the glass. Instead of a metallic layer covering the imprint, the pieces described here have ceramic inclusions which came from the ceramic pontil visible in section. It should be said, however, that although the outer part of the pontil was completely covered with glass, the paraison did not entirely surround the pontil. It almost seems as though the glass-worker picked up a gob of glass, but did not turn the stick round in it, so we now see a nicely curved outer rim, instead of a broken edge. This can be explained by the specific function that the stick fulfilled as a mandril.

\section{CONCLUSION}

There is no doubt that, as Stern hypothetically claimed several years ago (cf. above), ceramic tools were used in glass craft. Ceramic tools would have been a ready available and cheap solution to the technical problems a glass-worker encountered while making vessels. With this article we hope that ceramic tools used in glass-making will be recognized during excavation in the future, and that a general framework for the analysis of ceramic glass-working tools will be created.

\section{Acknowledgements}

The authors would especially like to thank Marianne Stern for her enthusiasm and generosity, and for her kind discussions from which the research greatly benefited, Heidi Amrein for useful comments, pictures and literature, and Sylvia Funschilling for encouraging us to publish this enigmatic object. Additional thanks for photographs go to Bruno Vandermeulen (KUL), to Eliane Mahy (KUL) and Bieke Van Gompel for illustrations, and to Ezra Erb for revising the text.

3 For a detailed overview of the history of the use of the pontil, see Stern $(1999,448-50)$. 
This research is supported by the Interuniversity Attraction Poles Programme-Belgian Science Policy (IUAP VI/9) and the Fund for Scientific Research-Flanders (Belgium) (FWO, project FWO G.0245.02)

(VL and MW) Sagalassos Archaeological Research Project Katholieke Universiteit Leuven M. Theresiastraat 21 B-3000 Leuven Belgium

E-mail: veerle.lauwers@arts.kuleuven.be (PD) Centre for Archaeological Sciences Section Geology Katholieke Universiteit Leuven Celestijnenlaan 200E B-3001 Leuven E-mail: patrick.degryse@geo.kuleuven.be

\section{REFERENCES}

AMREIN, H. 2001: l'Atelier de verriers d'Avenches. l'Artisanat du verre au lieu du ler siècle (Lausanne). Degryse, P., POBlome, J., DONNERS, K., DECKers, J. and WAELKENS, M. 2003: Geoarchaeological investigations of the 'Potters' Quarter' at Sagalassos, Southwest Turkey. Geoarchaeology 18, 255-81.

DEGRYSE, P., SCHNEIDER, J., POBlome, J., WAELKENS, M., HAACK, U. and MUCHEZ, P. 2005: A geochemical study of Roman to Early Byzantine glass from Sagalassos, Southwest Turkey. Journal of Archaeological Science 32, 287-99.

DEGRYSe, P., SCHNEIDER, J., HAACK, U., LAUWERS, V., POBlOME, J., WAELKENS, M. and MUCHEZ, P. 2006: Evidence for glass 'recycling' using $\mathrm{Pb}$ and $\mathrm{Sr}$ isotopic ratios and $\mathrm{Sr}$-mixing lines: the case of Early Byzantine Sagalassos. Journal of Archaeological Science 33, 494-501.

FREESTONE, I.C., LESLIE, K.A., THIRLWALl, M. and GORIN-ROSEN, Y. 2003: Strontium isotopes in the investigation of early glass production: Byzantine and early Islamic glass from the Near East. Archaeometry 45, 19-32.

FREESTONE, I.C., WOLF, S. and THIRLWALL, M. 2005: The production of HIMT glass: elemental and isotopic evidence. Annales du l6e congrès de l'Association Internationale pour l'Histoire du verre (London), $153-7$.

HENDERSON, J., EVANS, J.A., SLOANE, H.J., LENG, M.J. and DOHERTY, C. 2005: The use of oxygen, strontium and lead isotopes to provenance ancient glasses in the Middle East. Journal of Archaeological Science 32, $665-73$.

LAuWers, V., Degryse, P., POBlome, J. and Waelkens, M. 2005: Le verre de Sagalassos: de nouvelles preuves d'une production locale de verre. Bulletin de l'association française pour l'archéologie du verre, 26-9.

LAUWERS, V., DEGRYSE, P. and WAELKENS, M. in press: Evidence for glass working in Anatolia in antiquity. The case of Sagalassos (Pisidia, SW Turkey). Journal of Glass Studies.

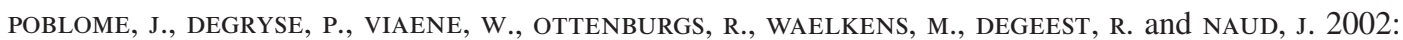
The concept of a pottery production centre. An archaeometrical contribution from ancient Sagalassos. Journal of Archaeological Science 29, 873-83.

STERN, E.M. 1992: A 4th Century Factory for Gathering and Blowing Chunks of Glass. Review of Weinberg (ed.), Excavations at Jalame, site of a glass factory in late Roman Palestine. Journal of Archaeological Scieuce 5, 490-4. 
STERN, E.M. 1995: Roman mould-blown glass: the first through sixth centuries (Rome).

STERN, E.M. 1999: Roman Glassblowing in a Cultural Context. American Journal of Archaeology 103, $446-8$.

STERN, E.M. 2001: Roman, Byzantine and Early Medieval Glass: Ernesto Wolf Collection (Ostfildern-Ruit). STERN, E.M. 2004: The glass banausoi of Sidon and Rome. In Baretta, M. (ed.), When glass matters (Florence, Studies in the history of science and art from Graeco-Roman antiquity to early modern era), 87-9.

STERN, E.M. 2005: Les origins du soufflage du verre. Bulletin de l'association française pour l'archéologie du verre, $16-18$.

STERN, E.M. and SCHLIEK-NOLTE, B. 1994: Early glass of the ancient world 1600BC-AD50: Ernesto Wolf Collection (Ostfildern-Ruit).

WEDEPOHL, K.H. and BAUMAnN, A. 2000: The use of marine molluskan shells for Roman glass and local raw glass production in the Eifel area (western Germany). Naturwissenschaften 87, 129-32. 